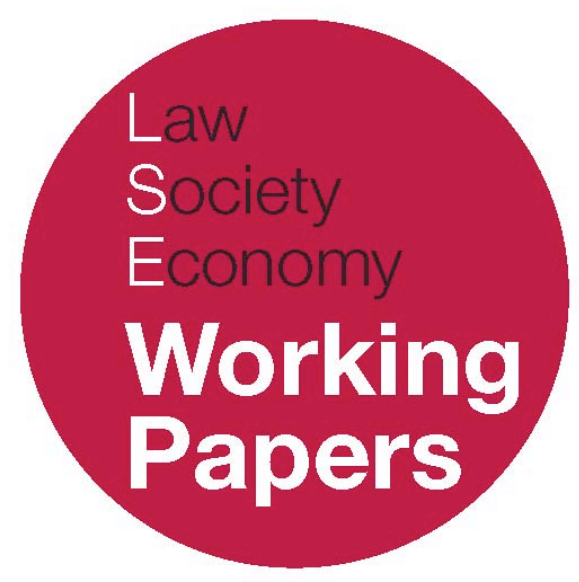

\title{
The Devil's Account: Men, Morals, and Constitutional Goods
}

\author{
Thomas Poole
}

LSE Law, Society and Economy Working Papers 1/2009

London School of Economics and Political Science

Law Department

This paper can be downloaded without charge from LSE Law, Society and Economy Working Papers at: www.lse.ac.uk/collections/law/wps/wps.htm and the Social Sciences Research Network electronic library at: http://ssrn.com/abstract $=1331370$.

(C) Thomas Poole. Users may download and/or print one copy to facilitate their private study or for non-commercial research. Users may not engage in further distribution of this material or use it for any profit-making activities or any other form of commercial gain. 


\title{
The Devil's Account: Men, Morals, and Constitutional Goods
}

\author{
Thomas Poole*
}

\begin{abstract}
Alan Brudner's constitutional theory offers us an ideal constitution or 'heaven of laws'. His theory maps a constitution heavy with law. Law permeates and supports a host of dense networks and relationships between individuals, communities and the state. It also specifies a very comprehensive set of rights. These detailed prescriptions are designed to take constitutional form, with the result that they are removed largely from the remit of normal political and ideological debate. This paper probes this vision of constitutional order. It focuses on two particularly revealing aspects of the theory - its Aristotelian perfectionism and the educative role it affords the state. Drawing on an older tradition of liberal thought exemplified by Hume, the paper concludes that the extremely 'thick' legal constitution of the type Brudner presents is not one to which liberals should subscribe. His 'heaven of laws', since it envisages a state of political changelessness, amounts ultimately to a particular sort of tyranny in which the individual is trapped once more by the bonds of fate.
\end{abstract}

\footnotetext{
${ }^{*}$ London School of Economics. I would like to thank Alan Brudner for his comments on the original draft of this article and Philip Cook for his remarks on a subsequent version. This paper is part of a collection of essays examining important aspects of Alan Brudner's Constitutional Goods (Oxford: Oxford University Press, 2004). It first appeared as a paper presented at a symposium organized by the LSE Legal \& Political Theory Forum and hosted at the London School of Economics on 9-10 May, 2008. A modified version of this article is published in the current issue of the Canadian Journal of Law and Jurisprudence (2009) 1. The organizers, Philip Cook and Thomas Poole, would like to thank both the LSE and the LSE Law Department for supporting this event.
} 


\section{INTRODUCTION}

William Blake ... put the argument this way: 'It indeed appear'd to Reason as if Desire was cast out; but the Devil's account is, that the Messiah fell, \& formed a heaven of what he stole from the Abyss." But if the heaven of laws that bounds freedom of conscience is freedom's own creation, may not freedom now dwell within it?' (Constitutional Goods, 439)

Constitutional Goods, a work of political theory presented as constitutional theory, foregrounds law. Law is central to its method. The dialogic (or inclusive) theory developed in the book is based, we are told, on 'a unity of elements found in actual case law'. ${ }^{1}$ Law provides, then, much of the raw material on the basis of which the three conceptions of liberalism (libertarian, egalitarian and communitarian) are identified. And court cases are vital to the process of 'sifting' through which aspects of each conception that are of enduring value are identified and synthesized within a final 'inclusive conception' of the liberal constitution. ${ }^{2}$ Law is also central substantively. It plays a role in the high moment of the theory the mutual recognition of citizen and ethos - and permeates (and justifies) every mode of social and political interaction within the ideal political community that Constitutional Goods presents. State, community, and individual are wrapped up and enfolded within law (or, as Brudner prefers to style it, 'the Law') within the inclusive theory.

This paper looks closely at the role law plays in Constitutional Goods. Part I examines the legal aspects of Constitutional Goods and makes some general claims about the way in which law is conceived within the inclusive theory. Part II concentrates on the legal aspects of the theory's emphasis on Aristotelian perfectionism and the pedagogical role for the state. While interesting and important in their own right, these aspects of the theory allow us to shed light on the conception of law that predominates within the theory. Part III offers something of a Devil's account, offering in response to Brudner's Hegelian idealism an alternative approach grounded in Humean scepticism. Brudner adverts to this approach towards the end of Constitutional Goods, but only to dismiss it. I want to pursue this avenue of inquiry as a basis from which to argue that the 'heaven of laws' that Brudner imagines is a goal which is neither particularly liberal nor especially desirable.

\footnotetext{
1 Constitutional Goods (Oxford: Oxford University Press, 2004), 1 (CG). See also at 12: 'the aim of const the is to gain the public standpoint from which to sift from the constitutional jurisprudence of liberaldemocratic courts principles of political justice for a liberal democracy and from which to present the best available justification of these principles to adherents of various philosophic views of justice, all of whom share a core belief that makes them liberals.'

2 For an account of the argument and method of Constitutional Goods see T. Poole, 'The Return of Grand Theory in the Juridical Sciences?' (2007) 70 Modern Law Review 484.
} 


\section{THE INDIVIDUAL AND THE LAW}

What, then, does the 'heaven of laws' envisaged in Constitutional Goods look like? Let us begin by exploring the core of Brudner's conception of the relationship between state, community (or cultural groups) and individual. The state is itself understood as a community (or ethos) and, this being so, is treated by the inclusive theory as an end in itself - an end, indeed, that is, in a sense, superior to all others. It is, Brudner says at one point in the text, 'the architectonic end that relativizes and subordinates the others' whose purpose it is to 'unify people sharing a common life, to perpetuate that life, and to confer distinction on those who contribute to it.' This understanding of the nature and function of the state shows Brudner's theory at its most Hegelian. Hegel says that the 'state is the actuality of the ethical Idea - the ethical spirit as substantial will, manifest and clear to itself, which thinks and knows itself and implements what it knows in so far as it knows it'. ${ }^{3}$ Brudner puts it this way:

As the best expression of living ethos, the state is a telos for the identity groups it encompasses. It is thus understood here ... as the powerful representative of a common life, a focus for patriotic identification and compatriot solidarity rather than a servant of the welfare of atomistic persons. ${ }^{4}$

This passage comes from Brudner's discussion of the communitarian constitution, and so represents an intermediate stage in the argument..$^{5}$ It might be suggested, then, that this reading does not accurately reflect Brudner's fully developed theory of the state. But the process of mutual recognition which gives rise to the inclusive constitution - the moment in which tensions between individual and community are transcended so that, as it were, the two become one - does little to alter previous perceptions. Unfortunately, the relevant passages in Constitutional Goods

\footnotetext{
3 G.W.F. Hegel, Elements of the Philosophy of Right (Cambridge: Cambridge University Press, ed. A.W. Wood, 1991) \257. See also at $\$ 261$ : 'the state is on the one hand an external necessity and the higher power to whose nature their [the spheres of the family and civil society] laws and interests are subordinate and on which they depend. But on the other hand, it is their immanent end, and its strength consists in the unity of its universal and ultimate end with the particular interest of individuals, in the fact that they have duties towards the state to the same extent as they also have rights.'

${ }^{4} \mathrm{CG}, 305$.

5 Although it is unarguable, to my mind, that in Hegel's theory - on which Brudner draws heavily - the state retains its status as ultimate telos even within what Brudner describes as Hegel's notion of developed ethical life (Sittlichkeit). The state, Hegel tells us, has its immediate (or undeveloped) existence in custom and its mediate (or developed) existence in the self-consciousness of the individual. See, e.g., n 3 above, $\mathbb{S}$ 258: 'The state is the actuality of the substantial will, an actuality which it possesses in the particular selfconsciousness when this has been raised to its universality; as such, it is the rational in and for itself. This substantial unity is an absolute and unmoved end in itself, and in it, freedom enters into its highest right, just as this ultimate end possesses the highest right in relation to individuals [die Einzelnen], whose bighest duty is to be members of the state ... The state in and for itself is the ethical whole, the actualization of freedom, and it is the absolute end of reason that freedom should be actual. The state is the spirit which is present in the world and which consciously realizes itself therein ... The state consists in the march of God in the world, and its basis is the power of reason actualizing itself as will.'
} 
are cryptic, making the interpretative task much harder than it should be. Consider these lines from the critical part of the text:

To say that living ethos fails fully to respect the autonomous self its own form requires is to say that, insofar as it is confined to living ethos, ethical life is not yet fully itself. ... [C]onfined to living ethos, ethical life lacks the morally independent agent as that without whose free recognition of ethical life (i.e. its structure of mutual recognition) as the form of valid worth- and authority-claims it (ethical life) must remain at odds with itself as a conception of public reason. And if ethical life lacks the autonomous self, then that self complements ethical life and finds its rational worth in reproducing and recognizing its structure of mutual recognition as the form of valid law. However, the individual of whom we are now speaking is no longer one immersed in an ethos; rather, it is one who has left ethos behind as a sufficient basis of its dignity ... A new conception of public reason has now come forwards. It is the mutual recognition of (the mutual recognition structure of) ethical life and the self who claims to be self-supporting. ${ }^{6}$

I refer to this as the inclusive theory's 'Zarathustra moment', ${ }^{7}$ an apt moniker given not just the quasi-miraculous resolution that occurs at this point, but also the uncharacteristically vague and esoteric manner of its exposition. Seeking to avoid the pitfalls of standard communitarian accounts, in which the individual is often lost in the desire to protect 'living ethos', Brudner (following Hegel) identifies a mode of being - developed ethical life - in which community and the autonomous self become one so that each may be fully realized. The autonomous individual, we are told, 'complements ethical life and finds its rational worth in reproducing and recognizing its structures of mutual recognition as the form of valid law.' ${ }^{8}$ The autonomy-claiming individual and the state/community (understood as an end in itself) are initially to be found in opposition. But after the process of mutual recognition they combine in (or perhaps more accurately to form) the dialogic (or inclusive) constitution, which is understood as an ideal or archetype of the liberal constitution. This process of mutual validation is central to the theory, since it generates the basis for the integration of all three constitutional paradigms - libertarian, egalitarian and communitarian.

We can express this analysis of the mutual recognition process in a different, slightly more formal, way. Brudner claims that, whereas the individual plus the state does not equal the ideal liberal constitution, the individual and the state together do equal the ideal liberal constitution where 'together' equals the process of mutual recognition. The idea that the prior opposition between individual and state itself helps to generate a situation which transcends it clearly needs some defending, particularly in light of the rather unilluminating unfolding of the mutual

${ }^{6}$ CG, 318-9.

7 n 2 above.

${ }^{8} \mathrm{CG}, 318$. 
recognition story. What does it mean to say that a new conception of public reason 'has now come forward'? How precisely did this occur? And through what process of constitutional alchemy was the prior antithesis between individual and community dissolved away? I am sure that it would help to be a devotee of Hegelian dialectics to appreciate the argument. (Bernard-Henri Lévy describes the dialectic as 'That Supreme Court of human misery, without appeal or recourse', a phrase that is not entirely without resonance in the current context. $\left.{ }^{9}\right)$ But those of us who remain agnostic about that method may also be nonplussed by Brudner's additional argument that the validity of the new constitutional paradigm rests on claims that are simultaneously both false and not false: 'the mediate atomist claims that the first claim [that the individual is self-supporting] is false but nonetheless supported as necessary (belonging) to the rule of Law (here the structure of ethical life) and the publicity of public reason. ${ }^{10}$

The exegetical task is complicated at this point, then, but I think the best reading has Brudner sticking close to his Hegelian prototype. 'The state', Hegel writes at a roughly equivalent stage in his account, 'is the actuality of concrete freedom. But concrete freedom requires that personal individuality [Einzelheit] and its particular interests should reach their full development and gain recognition of their right for itself (within the system of the family and of civil society), and also that they should, on the one hand, pass over of their own accord into the interest of the universal, and on the other, knowingly and willingly acknowledge this universal interest even as their own substantial sprit, and actively pursue it as they ultimate end.'11 Brudner does not seem to repudiate what he says earlier in the development of his constitutional paradigm about the state being an end in itself. What the inclusive conception specifically rejects in communitarianism by means of the 'sifting' process is its 'despotism of ethos'.12 But this is achieved not so much by objecting to specific claims communitarians make but rather, first, through the argument that the communitarian constitution (like the libertarian and egalitarian constitutions before it) is incomplete when considered as a self-standing constitution and, second, by the transcendental process of mutual recognition, which I have just described, in which community and individual recognize each other, thus becoming fulfilled. True, Brudner on occasion talks about his revised communitarian conception as though it amounted to watered down ethos. He says, for instance, that 'the common life [within the inclusive conception] is no

${ }^{9}$ B.H. Lévy, Left in Dark Times: A Stand Against the New Barbarism (New York: Random House, 2008) 71. See also E. Levinas, Difficult Freedom: Essays on Judaism (Baltimore: Johns Hopkins University Press, trans S. Hand, 1990).

${ }^{10}$ CG, 319. Brudner has another stab at making the point on the following page: 'Though atomism is in one sense false, the mistaken claim that the individual is self-supporting is itself supported in public reason, for ethical life would not be a form of valid Law without an independent self to confirm it as such.'

11 n 3 above, $\mathbb{\int}$ 260. See also C. Taylor, Hegel and Modern Society (Cambridge: Cambridge University Press, 1979) 51: 'Freedom is only real (wirklich) when expressed in a form of life; and since man cannot live on his own, this must be a collective form of life; but the state is the collective mode of life which is backed by the full power of the community; and thus freedom must be embodied in the state.' 12 CG, 306. 
longer a national ethos but a constitutional law that is in its essentials common to all liberal polities. ${ }^{13}$ But this claim should be read alongside three others: first, his defence of the state-specific nature of the ideal constitution ${ }^{14}$; second, the acceptance of most of the essentials of the 'communitarian narrative' including progress to a goal of the individual's identification with communities and subcommunities (families, cultural groups and state) $;{ }^{15}$ third, the espousal of a very 'thick' (and culture-heavy) constitutional framework - a dimension of the theory that I focus on later in this paper.

The influence of the 'communitarian reformation'16 is also very much evident in the way the inclusive theory describes the relationship between individual and community (as distinct from state). Community is also a constitutional good, 'an end in the Aristotelian sense', through which the individual gains worth and fulfillment. ${ }^{17}$ The strong communitarian strand to Brudner's theory prevents the subordination of community groups and cultures to the state, and requires the state to provide even-handed support to all cultural groups, as well as to those social institutions that support the individual (chiefly, families and corporations). ${ }^{18}$ Communities, then, have rights too: 'If liberal governments have a duty of concern for cultures, then cultures have, in a manner of speaking, correlative rights to concern'. ${ }^{19}$ These rights, which are exercisable by the group qua group and not just by individuals, are far from negligible: the constitutional good of cultural membership is capable of overriding libertarian rights (subject to limitations). ${ }^{20}$ There are limits, however, to the state's duty to accommodate cultures. Nonegalitarian practices within groups are owed a duty of respect that falls short of a duty of support. ${ }^{21}$ The state also has a duty to educate cultural groups whose practices do not meet the standards required by the libertarian and egalitarian principles. And, in the final analysis, the state has an obligation to prevent certain group practices - 'the inclusive conception places limits on what cultural communities may validly do to their members in the name of their ethos'.22

The place of religion in the inclusive theory is particularly revealing. Religions ('communities of belief') are cultures and, as such, are to be treated as constitutional goods by the state. But this relationship is a two-way street. Not only must the state support religious groups, but religion can also be put to good use by the state.

${ }^{13} \mathrm{CG}, 320$

${ }^{14} \mathrm{CG}, 320$ : 'the civil and political rights of equal moral agents are confirmed within a framework that also vindicates the communitarian conception that the self-sufficient community is a bounded political community rather than a cosmopolitan order of free and equal selves.'

${ }^{15}$ CG, 320-1.

${ }^{16} \mathrm{CG}, 304$.

${ }_{17} \mathrm{CG}, 302$

18 Brudner uses interchangeably the terms: communities (including religious communities); cultures; cultural groups.

${ }^{19} \mathrm{CG}, 363$

${ }^{20} \mathrm{CG}, 364$.

21 CG, 380 .

22 CG, 428. 
In providing even-handed support to religious schools and communities, in adopting school prayers and non-denominational religious symbols (for example, 'in God we trust' or the reference to the 'supremacy of God' in the preamble to the Canadian Constitution), the liberal state does not endorse religion over irreligion or encourage people to become religious; rather, it enlists the services, and encourages the allegiance, of those who are religious in promoting an end that both believer and non-believer can embrace. ${ }^{23}$

This passage comes late in the book (on page 386), substantially after the mutual recognition story which marks the theoretical 'journey' from undeveloped to developed ethical life (pages 316-323). So there is no reason to read it as anything other than as part of Brudner's final conception of the ideal constitution. It also mirrors Hegel's position on the subject. Hegel, Brudner's originary source, articulated a similarly entangled relationship between state and religion. Recognizing the power of religion to cement the legitimacy of the state - it is 'within this relationship that the state, laws, and duties all receive their highest endorsement as far as the consciousness is concerned' - Hegel argued that religion 'constitutes the foundation which embodies the ethical realm in general, and, more specifically, the nature of the state as divine will'. Although antithetical towards anti-social religions and sects that, as he put it, turn 'religiosity into a polemical kind of piety', Hegel argued that a 'genuine' religious group which does not have a 'negative and polemical attitude towards the state, but acknowledges and endorses it' will enter into a relationship with the state. 'It is in the nature of the case that the state fulfils a duty by giving the [religious] community every assistance and protection in the pursuit of its religious end. Indeed, since religion is that moment which integrates the state at the deepest level of the disposition [of its citizens], the state ought even to require all its citizens to belong to such a community - but to any community they please'. ${ }^{24}$

The intertwining of religion and state exemplifies Brudner's treatment of the relationship between state and community in general. It is a complicated relationship, often intimate, as one might expect from a theory that draws so heavily on communitarianism. ${ }^{25}$ The state has (pretty strong) duties of respect and accommodation that it owes to cultural groups, and these groups have correlative rights that can be vindicated against the state. And, while the state must try to deal even-handedly with groups, it is not supposed to be neutral. Groups that fall short of egalitarian or libertarian standards are to be educated and if necessary reformed. But the state also stands to profit from this network of relationships, gaining allegiance from groups from the way it treats them with respect, ${ }^{26}$ and deploying

23 CG, 386.

${ }^{24} \mathrm{n} 3$ above, $\int 270$. See also $i d$. 'It is philosophical insight which recognizes that Church and state are not opposed to each other as far as their content is concerned, which is truth and rationality, but merely differ in form.'

${ }_{25}$ CG, 428: 'Dialogic community is itself a communitarian conception of public reason'.

26 The relationship probably goes deeper than this analysis suggests. Brudner's recipe for democracy - 
cultural (partisan) ideas and symbols for its own ends. The inclusive theory, then, offers a vision of a political order in which state and community are both (highly) valued as ends in themselves - above and beyond their simple instrumental value to individuals - and in which both are joined in a close relationship of cooperation and mutual endorsement.

The state (and law) plays a primary role in cementing the (dense) set of relationships between individual and cultural group in the inclusive theory. The state has a duty to uphold the principles of the inclusive theory, and these principles together describe a 'deep, substantive, and, for all that, inclusive'27 conception of the good life. 'Such a life includes respect for liberty and private property, public concern for self-authorship and self-rule, as well as public support for the communities - familial, cultural, professional, and political - within which individuals are socially confirmed as valued ends. ${ }^{28}$ The state must provide the conditions required for every individual to lead the kind of life he or she values, an obligation which includes the duty to foster the cultural conditions that the theory sees as necessary for individual fulfilment. For, as we have seen, individual and community are joined in a structure of mutual recognition, the one providing recognition and fulfilment for the other: 'The well-ordered community and the well-ordered personality are mutually confirming.' This being so, the state has a duty to support and encourage this state of being. The resulting picture is one of coherence and cohesiveness - a political community structured around and striving towards the perfection of a particular political conception. Or, as Brudner observes when discussing hate speech: 'It is good for individuals that their racial identities be integrated into cultural ones and that their cultural identities be integrated into political citizenship. ${ }^{29}$ One consequence of this arrangement is that the citizen immersed ('free-fully'?) in ethos - seems to exist almost at arm's length to the state. Most of the direct dealing that occurs seems to go on between group and state - a position reinforced by Brudner's favoured democratic model, 'representation by corporation' (that is, via groups). ${ }^{30}$

We are now in a position to contemplate the nature of law under the inclusive conception. Law is unitary - there is one rule to bind them, and this is the rule of (state) Law: i.e. an authoritative normative structure which replicates the principles of the inclusive theory. Law is pervasive - the inclusive conception articulates a constitution heavy with law. The inclusive theory maps a highly juridified world, ${ }^{31}$ in which law (or Law) permeates, shapes and justifies a host of (often 'dense') networks and interrelationships. Brudner argues, however, that not all the law within the inclusive conception is 'hard' law - in part, I suspect, in order to mitigate what would otherwise be the almost palpably stifling nature of the

'representation by corporation' - is essentially group-based democracy (in which individuals are represented by groups or corporations - organizations to which they have a 'life-pervasive commitment'). $27 \mathrm{CG}, 426$.

$28 \mathrm{CG}, 426$.

${ }^{29} \mathrm{CG}, 368$

${ }^{30} \mathrm{CG}$, ch 11

${ }^{31}$ G. Teubner (ed), Juridification of Social Spheres (Berlin: De Gruyter, 1987). 
constitutional order he advocates. He articulates, on occasion, 'softer' forms of law, preferring instruction and persuasion rather than rules or injunctions backed by sanctions. (I examine this claim in the next section.) Law in the inclusive conception is also (a variant of) natural law - a position which has its clearest expression in the related claim that 'a ruler's claim of authority is not valid unless he rules under the inclusive conception' 32 and that a judge must refuse to apply a law that 'no conception of public reason could support, and he must do so precisely in his capacity as judge'. ${ }^{33}$ (Although how this might mean anything over than that a judge must refuse to apply any law that is unsupported by the inclusive conception is a mystery to me, given both the preceding claim - a ruler can only claim authority insofar as it rules under the inclusive conception - and Brudner's grand theoretical enterprise.)

But three other (related) features of the concept of law defined in Constitutional Goods are especially noteworthy. First, the Law described by the inclusive conception is constitutional law. This means that it has a special higherorder status that largely immunises it from political change. To begin to appreciate the implications of this position, we need to know precisely what the inclusive theory is seeking to immunise. And the list is extensive. In addition to the 'standard catalogue' of civil and political rights, the inclusive theory also elaborates a very comprehensive set of social and economic rights. These rights include: a right to conditions of moral independence (which includes the right to child nutrition and publicly funded education); the right to the conditions of civil independence (encompassing, for instance, the right of collective bargaining, compulsory trade union membership, and the right to strike); a right to the material and social conditions of self-actualisation (embracing financial aid for professional education, the provision of student loans, social security, paid maternity leave, subsidies for child care, and anti-discrimination legislation). In addition, these entitlements must benefit individuals regardless of their ability to pay and cannot derive exclusively from insurance based schemes. ${ }^{34}$

Second, the ascription of constitutional status to laws lends itself to a constitutional structure in which courts are central actors. The inclusive theory is no exception in this regard, charging courts with a duty to act as interpreters of what the inclusive conception means in practice. Brudner does not go as far as committing to a model in which courts are sovereign constitutional actors. A fairer reading of his position would be one in which the court shares sovereignty with the legislature. But it remains true that the courts wield enormous power within the constitutional order enshrined by the inclusive conception. They must interpret, articulate and apply the dense and detailed bundle of rights and duties described by the inclusive theory. Brudner is adamant that the obligations entailed by the inclusive conception are 'not only binding in conscience or in the political

\footnotetext{
32 CG, 432.

33 CG, 434.

${ }^{34}$ CG, 264-7.
} 
arena but also compellable in a court of law'. ${ }^{35}$ In addition to 'ordinary' powers of judicial review - which here means constitutional review as well as the review of administrative action - their remit includes the power (and duty) to command the fulfilment of the state's affirmative obligations de novo and the power (and duty) to rewrite legislative programmes or benefit-conferring laws which fail to treat like persons alike. ${ }^{36}$ And, while it is true that both of these powers are subject to 'democratic override', Brudner omits to mention that his model for that provision - section 33 of the Canadian Charter ${ }^{37}$ - is in practice virtually defunct at the Federal level. The process of constitutionalisation and judicialisation, once set in train, tends to have its own momentum, making democratic veto provisions particularly prone to being bypassed. ${ }^{38}$

Third, the consequence of the inclusive theory's idolisation of law (as Law) is the removal of ideology within the political community. Brudner sees this development as an unmitigated blessing - the instantiation of his 'heaven of laws'. Law becomes a substitute for ideology, sublimating the conflict that is inherent to a system in which different ideologies are in play. The internalization by the inclusive conception of 'much ideological controversy into the rule of Law', Brudner says, entails 'the contraction of the agenda of democratic politics'. Law's jurisdiction is 'vastly expanded at the expense of moral and political argumentation', a position which implies the 'absorption (and so cancellation) of the contest between rival fundamental conceptions' and so perhaps the 'end of ideology'. ${ }^{39}$ This is an important point in its own right - and I will return to address it later in the paper. But it is also deepens our observations about the constitutional status of Brudner's Law and the enhanced role such constitutionalization affords the courts. For the substitution of (constitutional) law for ideology also denotes a thorough, indeed almost complete, constitutionalization of politics - the rendering, that is to say, of a political structure of argument, debate and legitimation in a different (juridical) mode, one which is necessarily dominated by a different language, underpinned by a different normative structure and settled through a different inter-institutional dynamics.

\section{PERFECTING MAN}

I want to probe this conception of law further. To this end, I focus on two particularly revealing aspects of the inclusive theory - its perfectionism and the

35 CG, 277.

36 CG, 276-285.

${ }^{37}$ CG, 284: 'there is required the possibility of a democratic veto of a court's decision roughly along the lines of section 33 of the Canadian Charter.'

38 See, e.g., M. Tushnet 'New Forms of Judicial Review and the Persistence of Rights- and DemocracyBased Worries' (2003) 38 Wake Forest Law Review 813.

${ }^{39}$ CG, 438 . 
educative role for the state - which develop some of the more significant features of the conception.

\section{Educating THE Citizen}

Brudner says that his theory expresses 'an Aristotelianism adapted to the modern world'. ${ }^{40} \mathrm{He}$ means by this that the inclusive constitution specifies 'not simply a formal ideal of the autonomous personality ... but an exemplary way of life with a determinate content'. He also claims that this Aristotelianism is liberal for two reasons: first, because it has developed historically out of liberal conceptions of freedom and dignity; and, second, because 'the pattern of exemplary life' specified by the theory 'is woven loosely enough to leave room for infinite variations according to individual choice.' ${ }^{41}$ Political communities under the inclusive conception can thus be described as having a kind of double-headed telos - to foster conditions necessary for the self-sufficient life and to shape the personality of the individual so that he or she is capable properly of embracing the life so enabled.

I want to focus on the second of these goals - the shaping of a particular personality type. The underlining question is this: can a polity that tries to shape individual personality truly be liberal, even when its aim is to produce individuals suited, as it were, to liberalism? This is what Brudner has to say on the matter:

the end of constitutional order is an ideal type of personality - one whose fundamental ends are those of the self-sufficient life, who pursues each successfully and in moderation, and who, in enjoying his dignity to the full, displays the excellence of an historically human type confident of the finite individual's infinite worth. ${ }^{42}$

The ideal polity, structured around the norms of the inclusive conception, has a corresponding ideal personality. The state must aim to 'cultivate through laws and public education the personality whose fundamental aims are for the humanly necessary elements of the dignified life enjoyed together and in proper balance. ${ }^{43}$ It must do so, one presumes, with the assistance of the cultural and other groups with which it is in a relationship of mutual recognition (or symbiosis). The polity as a whole, then, works towards the creation of what might be called the harmonious individual. The desired personality is one that is comfortable both with being self-sufficient (in the sense described by the inclusive theory), and with the dense matrix of interlocking relationships between state and community which the theory prescribes. The individual lives in harmony with herself, her community,

${ }^{40} \mathrm{CG}, 429$.

${ }^{41} \mathrm{CG}, 323$. Brudner also claims that there is 'a teleological impetus toward constitutional orders whose end-point is the order governed by the inclusive conception.' (429)

42 CG, 430.

${ }^{43} \mathrm{CG}, 426$. 
and her state. Indeed, there is no good reason for her living any other way, as all the conditions - material, normative, cultural - that are needed for her to realise the good life are in place.

In examining this account, I want to pursue two lines of inquiry. First, how does the state go about producing harmonious individuals, besides putting in place those conditions in which such individuals might flourish? The state has a positive duty to enact laws designed to instruct citizens in the self-sufficient life. 'Softedged' laws and public education seem to be Brudner's vehicles of choice. So, speaking about hate speech, he argues that 'part of what is needed are laws that show individuals the way of life lacking in nothing of what is needed for the enjoyment of their dignity.' 44 Brudner prefers to think of the laws emanating from the inclusive conception as at least as often instructive as coercive. One reason he might want to do so is to neuter the otherwise potentially stifling quality of such a 'thick' set of constitutional principles. Or, as Brudner puts it, the application of laws under the inclusive conception 'must leave room for the individual's spontaneous endorsement of the self-community as his good.'

But a closer look at one of the very few examples in Constitutional Goods reveals a rather different picture. On the subject of hate speech, Brudner thinks that Canada has shown the way (itself a recurring theme of the book). He notes that several defences are available in Canadian law to a charge of promoting hatred towards an identifiable group. These include private conversations, and statements that are true or that the speaker had reasonable grounds for believing are true. Brudner concludes from this analysis that by punishing only 'lying, wilfully blind, or unreflective' examples of hate speech, the 'law teaches its lesson' against abstract racial or cultural self-identification. Its purpose is 'to instruct citizens in the self-sufficient life within bounds consistent with the right of self-authorship.'45 Let's leave aside considerations of the merits of this particular type of law and consider instead whether the hate speech law he examines deserve to be called 'soft' law, in the sense that it emphasizes instruction over coercion? The law is a pretty standard example of its type. ${ }^{46}$ It is a provision of criminal law, prohibiting certain forms of conduct. It offers a series of defences which excuse otherwise prohibited conduct. Those who fall foul of the provision are liable to prosecution, conviction and possible imprisonment (up to 2 years in the Canadian example). ${ }^{47}$ This is certainly education of a sort. Offenders are punished in order to 'teach them a lesson', while conviction also sends out a message (the legislator hopes) that this sort of conduct, and the attitude that underlies it, is unacceptable. But, while the language of education and instruction in this sense is not wholly inappropriate, to talk as though this represents a different, more considerate approach to law-making is misleading. There seems to be little material difference

${ }^{44} \mathrm{CG}, 368$.

${ }^{45} \mathrm{CG}, 367$.

46 M. Rosenfeld, 'Hate Speech Laws in Constitutional Jurisprudence: A Comparative Analysis' (2003) 24 Cardozo Law Review 1523

47 Canadian Criminal Code RSC 1985 c. C-46, s. 319(1)(a) \& (2)(a). 
between this provision and, say, laws that punish theft. The UK Theft Act 1968, for instance, requires the prosecution to show that the defendant appropriated the property of another with the intention of permanently depriving the other of it, and the defendant must have done so 'dishonestly'. The provision thus provides a lawful excuse or justification for appropriations which are not seen as unjustified (in a particular sense). I don't want to overstate the case. It is true that liberal systems tend to define a range of exemptions in proscribing conduct where such proscription has the potential to limit free speech or expression - like hate speech but also libel/defamation laws ${ }^{48}$ and doctrines relating to 'fighting words'. ${ }^{49} \mathrm{But}$, still, dressing them up as Brudner does as 'instructions' to citizens ought not to obscure the fact that these laws are not, as it were, citizenship classes in the abstract. Certainly, they provide advice of a sort to citizens. ('Do not dishonestly appropriate property belonging to another'; 'do not indulge in hate speech unless what you say or write falls within a protected category'.) But it is advice that comes packaged in a particular, coercive form. All criminal laws are fundamentally expressions of state power, ultimately enforced and applied through 'hard-edged' sanctions.

Things become even more problematic when we look at what the state can do with (and in the name of) religion. Recall that Brudner regards the expropriation by the state of religious slogans and symbols for its own ends as entirely valid. His position is more complicated when it comes to the use of religion as a basis for justifying specific laws. The inclusive theory accepts the neutrality principle $-\mathrm{a}$ feature of both the libertarian and egalitarian constitutions - enjoining 'government from endorsing the choice of religious belief over nonbelief. ${ }^{50}$ But that principle takes on a different - and much reduced - form in the inclusive constitution, which respects religions as 'cultures of a special kind'.51 Brudner argues that the state has good reasons for incorporating religion. They are 'grounds of individual worth and so part of a life sufficient for dignity'. They are also 'as cultures themselves ordered to a vision of the self-sufficient community', which means that they are in a position to 'contribute to educating citizens to the virtues necessary to sustain that community'.52 Brudner imagines, following Hegel, a partnership of a particular kind between state and religion: 'in recognizing religious communities', he says, 'the state makes possible their reciprocal recognition of the liberal state as ordered to a goal kindred to their own and so worthy of their allegiance.' This means, more concretely, that the inclusive theory has no objection to the even-handed support to religious schools and communities (of 'all the major world religions'). It also means, as we have seen, that the state is entitled to use non-denominational religious symbols for its own purposes.

\footnotetext{
48 See, e.g., New York Times Co. v Sullivan 376 US 254 (1964).

${ }^{49}$ See, e.g., Chaplinksy v New Hampshire 315 US 568 (1942); R.A.V. v City of St Paul 505 US 377 (1992).

${ }^{50} \mathrm{CG}, 384$.

51 Recall that this discussion occurs in the text after the mutual recognition process and is thus applicable to the inclusive theory in its final form.

52 CG, 385-6.
} 
At the end of this discussion, Brudner asks rhetorically whether it matters if citizens 'believe that the law originated in a supernatural revelation or whether it simply existed time out of mind? Would it matter ... if some people believed that the law against murder and theft originated on Mount Sinai?'53 This position is the logical culmination of Brudner's Hegelian reading of the relationship between state and religion. But let us examine it from a non-Hegelian standpoint. We can leave to one side what the religious might say about this, since we are interested here in the more general, political question concerning the state's relationship with (and attitude towards) the individual. Unfortunately, Brudner is once again unclear on a key point - here, the precise nature of the trade-off he envisages between the neutrality principle of libertarianism and egalitarianism on one hand, and the position of 'strong' communitarian theories which would require much more deferential treatment of religious communities on the other. A generous reading of the text would accept that the neutrality (or anti-theocratic) principle is preserved to the extent that the inclusive constitution prohibits the justification of specific laws on religious grounds. But this reading is hard to square with other features of the text, particularly Brudner's claim that there is nothing objectionable in people being encouraged in their belief that 'the law of murder or theft originated on Mount Sinai'. And why, given that the theory specifically allows for the justification of second-order or constitutional principles on religious grounds Brudner's examples being the idea of 'in God we trust' or the reference to the 'supremacy of God' in the preamble of the Canadian Constitution - should 'ordinary', less fundamental laws be subject to different (and higher) standards regarding how they may be justified?

We have identified, then, a theoretical problem - a lack of clarity and consistency in the articulation of the relationship between state and religion. But there is also a more basic problem with the argument at this point. It is certainly possible to read the text - which, while unclear at this point, certainly lends itself to this interpretation - as saying that all laws may be justified on religious grounds. If so, then there is nothing in the theory that precludes a government of, say, nonbelievers 'selling' a law, itself justified substantively by the principles of the inclusive conception, to its people using religious ideas, language and imagery. Of course, we know that this sort of practice occurs with regularity in some quarters. But to support it as a matter of ideal theory is undoubtedly problematic from the liberal perspective. Not only is it self-evidently paternalistic - involving, as it does, the deliberate manipulation of the public - but it also undercuts the essential liberal predisposition to deny legitimacy to laws and constitutions that invoke supernatural sources of authority. ${ }^{54}$ Opening the door to the legitimation of this type of action makes the inclusive theory susceptible to the kind of criticism Brudner himself levied against the pre-liberal constitution - the respublica Christiana

\footnotetext{
53 CG, 387.

54 The use of religion in this way must also count as an insult to the religious believer's sincerity, since it instrumentalizes religious belief for non-religious ends.
} 
- in which, as he memorably put it, the invocation of 'priestly dogma' served to prop up the 'despotism of those who held the keys to utopia'. ${ }^{55}$

\section{THE INDIVIDUAL AND THE LAW}

The second line of inquiry examines the position of the individual vis-à-vis the law that results from the inclusive conception. Consider what we have uncovered so far. The inclusive constitution fosters (and serves to justify) a series of dense networks that operate between the state on one hand and community (including religious) groups and corporations on the other. Its central claim is that the individual can only be fully realized through immersion in the life of a group, and that this cultural arrangement - the interlocking of ethos and ego - is to be supported by the state. The state's mission, then, is to foster not only a climate in which individuals might flourish, but also a type of individual suited to that climate. Model citizens are preferred - individuals who are liberal, moderate and comfortable with their embedded position within both community and state.

Immediate concerns about whether the inclusive conception has really managed to escape the trap into which (as Brudner recognizes) communitarian theories often fall - the trapping of the individual in the aspic of preordained (inherited) fate - are not assuaged by the suggestion that the state's educative role often takes the form of soft-edged law. For, as we have seen, it is misleading, although not entirely inaccurate, to describe the application of criminal law through the classic sequence of prosecution, conviction and sentence as though it described a 'soft-edged' process of civic instruction. Even if we were to accept Brudner's designation here, soft law can be said to bring with it problems of its own. Soft law is insidious, since it tends to be less clear as to its scope and (crucially) as to its limits, making it more open to manipulation by governments. In any case, the velvet glove, while it may mask the iron fist of state power, does little to blunt the force resulting from the blow. And it may even serve to make the impact all the more shocking.

And fears increase when we examine the model of democracy articulated in Constitutional Goods. For citizens are not represented in Brudner's model state directly but through corporations. A corporation, we are told, has three central features. First, it is an 'organization to which the individual member acknowledges a life-pervasive commitment and from membership in which he gains a socially recognized dignity and status'; second, 'the corporation is internally democratic'; third, 'the corporation performs quasi-political or welfare functions with respect to its members'.56 Examples include self-governing aboriginal communities, ethnic organizations, labour unions, business corporations (companies), and universities (but not women's groups). Multiple voting is possible, indeed likely, in this

55 CG, 57.

${ }^{56} \mathrm{CG}, 414$. 
structure, since voting for a representative as a member of one corporation does not preclude voting as a member of another. ${ }^{57}$

Brudner argues that representation by corporation is justified in two primary ways. First, it responds to inadequacies within existing systems in which representation by population dominates. Due to these inadequacies, 'an informal system of group representation springs up to supplement it'. Adopting representation by corporation 'formalizes the informal system', and holds out the possibility of making the informal system more 'transparent and subject to rational criteria of inclusion'. ${ }^{58}$ In addition, representation by corporation 'turns out to afford stronger representation to individuals than a system geared directly to the individual': 59

When the individual is presented as a member of a corporation, his or her particular interests are represented rather than excluded, and, moreover, are represented powerfully and continuously. They are represented, however, not within fragmented interest groups that have little incentive to regard the external costs of their actions, but within inclusive and centralized structures whose large and overlapping memberships pressure internally elected leaders to see their corporation's particular interests as bound up with the larger public interest. ${ }^{60}$

There are a number of problems with this theory of democracy, all of which serve to accentuate the individual's prone status within the inclusive theory. For one thing, the model seems to be predicated upon (and more suited to) a fairly static model of society. It is instructive to turn once again to Brudner's Hegelian source. Hegel advocated a model of representation through corporations that is, in key respects, very close to Brudner's own. Hegel used the term 'corporation' to refer to the 'intermediate estate, i.e. the estate of trade and industry'.61 A member of civil society 'in accordance with his particular skill, is a member of a corporation whose universal end is ... wholly concrete, and no wider in scope than the end inherent in the trade which is the corporation's proper business and interest.' 62 The corporation has the right to look after its own interests, to admit members 'in accordance with their objective qualification of skill and rectitude', to protect them from certain contingencies: 'In short, it has the right to assume the role of a second family for its members'. ${ }^{63}$ Hegel ties this account to the corporation to a static

\footnotetext{
57 The prima facie anti-egalitarianism of this measure is justified, casuistically, in the following way: 'having two votes to your neighbour's one only ensures proportional equality between determinate individuals whose politically representable private interests are different' (CG, 419).

58 CG, 418.

${ }^{59} \mathrm{CG}, 417$.

$60 \mathrm{CG}, 418$

61 n 3 above, $\int 250$.

62 ibid, \ 251.

63 ibid, \ 252 .
} 
model of society in which individuals both knew their place and were comfortable with it.

The individual attains actuality only by entering into existence [Dasein] in general, and hence into determinate particularity; he must accordingly limit himself exclusively to one of the particular spheres of need. The ethical disposition within this system is therefore that of rectitude and the honour of one's estate, so that each individual, by a process of self-determination, makes himself a member of one of the moments of civil society through his activity, diligence, and skill, and supports himself in this capacity ${ }^{64}$

While the individual often balks at the notion of committing himself to a particular estate, especially in youth, on maturing he realizes that to be somebody, he must belong to a particular estate. It is clear that this arrangement is political as much as socio-economic, since representation through corporation is bound up with Hegel's notion of the estates as mediating institutions within the polity. As well as ensuring that the state does not appear as an isolated and arbitrary power of domination, this arrangement stops individuals from presenting themselves as 'a crowd or aggregate; unorganized in their opinions and volition, and do not become a massive power in opposition to the organic state.' 65

Brudner plays down the static quality of his Hegelian source. Even so, it does peek through to the surface at times, nowhere more so than in the first limb of his definition of corporation as an organization to which the individual acknowledges a life-pervasive commitment and in which he gains a socially recognized dignity and status. Perhaps we shouldn't over-emphasise the importance of this idea of 'life-pervasive commitment' and the related notion of deriving social status through membership of a business (or similar) association to Brudner's account. He avoids using the term 'life-long commitment', for instance, and does not deny that individuals can change their membership of corporations as their interests and careers change. Nonetheless, one wonders whether this model of representation makes any sense outside an early $19^{\text {th }}$ century world of trade associations and fairly static social estates or classes. I certainly feel committed, in different ways, to the London School of Economics and the Welsh rugby team, but I'm not at all sure that I'd liked to be politically represented by either. And, in as much as Brudner's model preserves these features of the Hegelian original, its relevance to a $21^{\text {st }}$ century world of fluidity, (hyper)globalisation and the cult of individualism ${ }^{66}$ is very much in question.

Corporate representation seems ill-suited, then, to the temper of the times. It also seems to entail, contrary to Brudner's protestations, a decrease in the democratic 'voice' of (most) individuals. At the macro level, the argument that

64 ibid, $₫ 207$.

65 ibid, $\int 302$

66 A. Somek, Individualism: An Essay on the Authority of the European Union (Oxford: Oxford University Press, 2008). 
corporate representation is preferable since it 'formalizes' existing arrangements lobbying and the like - which favour the rich and powerful is flawed, since it would almost certainly give greater impetus to these arrangements while also serving to legitimate them. Far from remedying the present democratic process, then, corporate representation would simply entrench existing defects and make them even harder to resist. The resulting arrangement would amount to little more than a system of lobbying in excelsis, the capture of the political system by companies and other groups, and would almost certainly benefit the rich and powerful far more than any other social group. At the micro level, it is highly unlikely that individual members of a corporation will find an effective outlet for voice within corporate structures. Democracy in the inclusive theory - for the individual at least - only really operates within such structures. Now, it is hard to judge these matters by reference to existing practice, since Brudner's model of representation is nowhere in operation. The closest analogy, however, is not flattering to the theory. There has been much talk of late about 'shareholder democracy'. Shareholders in public limited companies have the right to attend the Annual General Meeting, ask questions of the board of directors and vote on any resolution put before them. They are also entitled to receive any information about important company business, such as bid approaches. The company is in a sense, then, a formally democratic structure. But sporadic efforts to use shareholder powers to effect change (e.g. to curb the salaries of directors or to induce companies to adopt more ethical practices) come to naught far more often than not. A study by Lucian Bebchuk, for instance, showed that in 1996-2002 there were fewer than two attempts each year to vote out directors of American firms worth over $\$ 200 \mathrm{~m} .{ }^{67}$ This is hardly surprising since, as the Economist observed, 'shareholders typically vote unthinkingly for what the incumbent board wants, much as citizens of the Soviet Union used to vote for their leaders. ${ }^{6} 68$ If shareholder democracy is anything to go by, then in all probability representation by corporation would lead to less 'voice' for those with little power and influence, and more power to those who control corporations - and the bigger the corporation, the bigger the gain.

Corporate representation also has serious implications for public reason and political equality. ${ }^{69}$ It undermines the structure of public reasoning by advancing a privatised and factional model to replace (in Rawls' terms) a partial 'comprehensive' model. ${ }^{70}$ Political argument and justification become defined in the corporate representation model by the norms and interests of particular corporations rather than by reference to the public good. This change would impact negatively on the obligation to seek democratic agreement on terms that could be shared by all citizens, producing precisely the type of divisive, parti pris

67 L.A. Bebchuk, 'A Case for Increasing Shareholder Power' (2005) 118 Harvard Law Review 833.

68 'No Democracy Please, We're Shareholders', The Economist, 29 April 2004.

69 I am grateful to Philip Cook for revealing to me this line of argument.

70 J. Rawls, Political Liberalism (New York: Columbia University Press, 1993). 
structure that Brudner criticizes in Young's 'politics of difference' model. ${ }^{71}$ Corporate representation undermines political equality too, since not all corporations are equal. Consider, for instance, the disparity between the political standing of members of a weak or minority group (a small trade union, for instance) compared with the members of large and powerful, or elite, organizations (large corporations, confederations of company directors, groups representing establishment figures etc.). The inequality in political - and, no doubt subsequently, civic - standing is a deeply unattractive, indeed regressive, aspect of the inclusive theory.

There are reasons to be concerned, then, with important elements of the inclusive constitution. I have argued that this conception presents a dense and static legal and social framework which would operate to favour corporate, religious and other cultural groups, reducing the individual's 'voice' within the system and helping to trap her in inherited social patterns. Corporate representation also probably entails a reduction in 'exit'. To exit from the corporate structure entails the disenfranchisement of the individual. This predicament is more likely to be faced by those with strong political and ideological convictions, those who are serious about their politics, and who see no corporation or combination of corporations as adequately reflecting their views, interests and convictions. And what about the rules of association that are to operate within this account? There seems to be nothing in the inclusive theory that would prevent corporations from maintaining high or specific entry qualifications for aspirant members. Brudner's conception, then, would not disallow the 'closedshop' labour association or the operation of jus sanguinis (or bloodline) rules of membership, for instance, assuming that the group in question is internally (formally) democratic. This reduction in the meaningful possibility of associating is another problematic feature of the model Brudner advocates.

But there is a deeper dimension to these concerns, one which I have alluded to already. Recall that the arrangements specified by the inclusive conception are intended to take constitutional form, removing from the agenda of 'ordinary' politics and making them largely immune from change. (That is, after all, the whole point of rendering anything in constitutional form.) The domain of politics is subsumed within the empire of law. Political argument now 'performs the more modest role of guaranteeing the legitimacy of political judgment within the spaces left open by fundamental principles'. ${ }^{72}$ (And those spaces are none too wide given the specificity of the constitutional principles the inclusive theory prescribes.) But the victory of (constitutional) law comes at a price. The detailed pattern of social, political and legal relationships articulated by the inclusive theory, and which I have argued is in key respects inimical to the interests of the individual qua individual, is designed to be entrenched, as it were, for all time. The lack of 'give' within the system raises the real danger of social and political ossification. By committing the polity to a

\footnotetext{
71 I.M. Young, Justice and the Politics of Difference (Princeton, NJ: Princeton University Press, 1990).

${ }^{72}$ CG, 417 (emphasis added).
} 
particular set of cultural, corporate and constitutional affiliations, it also narrows the options for the individual still further. The individual, who has already lost 'voice' within this framework, now faces reduced 'exit' options, since the inclusive constitution is deliberately structured so as to prevent change to its basic principles and operating conditions.

\section{THE DEVIL'S ACCOUNT}

Constitutional Goods ends with a flourish. Brudner quotes from Blake's The Marriage of Heaven and Hell - 'It indeed appear'd to Reason that Desire was cast out' - and asks rhetorically, 'if the heaven of laws is freedom's own creation, may not freedom now dwell within it?' I have already offered reasons why the conception defended in the book entails a scenario in which the individual may be suffocated, bound by ties of law and fate. This section extends this 'Devil's account', as Blake would call it. Having identified the inclusive theory's ultra-confident rationalism and its perfectionism as root causes for its stifling treatment of the individual, I turn to an older tradition to recapture the 'breathing space' around the individual that seems elemental to liberalism. Drawing particularly on Hume, a figure Brudner touches on but only to dismiss, I suggest the bare outlines of a more empirical and sceptical approach to constitutional politics.

Behind every liberal theory lies a theory of men and morals. The inclusive conception lacks a sufficiently 'rich' conception of the individual - one that can account for the diversity, complexity and sheer messiness of individual lives. Hume, by contrast, provides what Stephen Holmes calls 'an unprudish, unhysterical, and humorous view of men and morals'.73 Working from an 'experimental' (or observational) method, ${ }^{74}$ Hume defined a position against overassertive rationalists - those who believed that there are eternal fitnesses and unfitnesses of things, which are the same to every rational being that considers them'. He challenged, in particular, the 'suppos'd pre-eminence of reason above passion' in moral judgement. Reason acting alone, he argued, is incapable of producing desire or action. It is passion (particularly sympathy) that is at the root of moral action. ${ }^{75} \mathrm{He}$ also objected to the false 'love of simplicity' that underlay psychological reductionism, arguing instead that there are three primary motives for human action - interests, affection and principles. ${ }^{76}$ While motives are always

\footnotetext{
73 S. Holmes, Passions and Constraint: On the Theory of Liberal Democracy (Chicago: University of Chicago Press, 1996) 53.

74 'But would these reasoners look abroad into the world, they would meet with nothing that, in the least, corresponds to their ideas' (Hume, 'Of the Original Contract', in David Hume: Essays Moral, Political and Literary (Indianapolis: Liberty Fund, ed. E.F. Miller, 1985) 469-70)

75 D. Hume, A Treatise of Human Nature [1739] (Penguin, ed. E.C. Mossner, 1985) 509: 'Morals excite passions, and produce or prevent actions. Reason of itself is utterly impotent in this particular. The rules of morality, therefore, are not conclusions of our reason.'

76 Although this analysis arises in an essay on political factions, it can be taken as typical of his moral
} 
mixed, sometimes one motive may predominate. Interest - or self-interest - is generally the most powerful motive influencing human behaviour. It is also 'the most reasonable, and the most excusable ${ }^{777}$ of the three (because most common and natural). It also provides 'the original motive to the establishment of justice'. ${ }^{78}$ Affection describes those motivations 'which are founded on the different attachments of men towards particular families and persons'. Principle - the motive favoured by constitutional theorists today ${ }^{79}$ - Hume treats with a scepticism bordering on outright hostility. Arising from man's capacity to form attachments to notions or ideas, 'abstract speculative principle', he says, is 'perhaps the most extraordinary and unaccountable phaenomenon, that has yet appeared in human affairs.' It is the origin, he thinks, of religious wars and divisions. Two men passing each other on the highway can easily pass each other. But not if they hold different principles: 'such is the nature of the human mind, that it always lays hold on every mind that approaches it; and as it is wonderfully fortified by an unanimity of sentiments, so is shocked and disturbed by contrariety. ${ }^{2} 0$

Hume's theory of moral judgement entails, then, 'a reduction in the role assigned to reason in the formation of judgement, and a corresponding increase in the role assigned to the imagination. ${ }^{81}$ The individual, on Hume's account, is invariably - universally - a passionate creature, motivated by desire, and whose rationality enables him to distinguish the costs of alternative courses of action. ${ }^{\prime} 82$ The argument against moral reductionism (including an argument against the use of ciphers) generates an argument about the imperfectability, both of man and of political arrangements. ${ }^{83}$ This lends itself to a position of ('moderate' or 'mitigated') scepticism about politics and law. ${ }^{84}$ The Humean instinct is to treat arguments that set out to establish legal and political arrangements on a lofty basis with suspicion. 'I am apt', he wrote, 'to entertain a suspicion, that the world is still too young to fix many general truths in politics. ${ }^{85}$

This (brief) survey of Hume's approach may offer clues about why the inclusive theory ends up trapping the individual in the constitutional equivalent of

theory as a whole. For a similar approach, see C. Kukathas, The Liberal Archipelago: A Theory of Diversity and Freedom (Oxford: Oxford University Press, 1993) 43.

77 D. Hume, 'Of Parties in General', in n 74 above, 59.

${ }^{78}$ Hume, $\mathrm{n} 75$ above, 547: 'tis only from the selfishness and confin'd generosity of men, along with the scanty provision nature has made for his wants, that justice derives its origin.'

${ }^{79}$ See, classically, R. Dworkin, A Matter of Principle (Cambridge, MA: Harvard University Press, 1985).

80 'Of Parties in General', 60-1. See also 'Of the Original Contract', 465: 'As no party, in the present age, can well support itself, without a philosophical or speculative system of principles, annexed to its political or practical one; we accordingly find, that each of the factions, into which this nation is divided, has reared up a fabric of the former kind, in order to protect and cover that scheme of actions, which it pursues.'

${ }^{81}$ D. Miller, Philosophy and Ideology in Hume's Political Thought (Oxford: Oxford University Press, 1981) 33.

82 n 76 above, 48.

83 'There is one mistake, to which they seem liable, almost without exception; they confine too much their principles, and make no account of that vast variety, which nature has so much affected in all her operations. When a philosopher has once laid hold of a favourite principle, which perhaps accounts for many natural effects, he extends the same principle over the whole creation, and reduces to it every phaenomenon, though by the most violent and absurd reasoning.' (Hume, 'The Sceptic', n 74 above, 159) $84 \mathrm{n} 81$ above.

85 Hume, 'Of Civil Liberty', n 74 above, 87. 
a gilded cage. Hume's position provides a basis for avoiding the suggestion of 'casting desire out', since desire (and related 'passions') is a necessary condition for personality (and indeed political judgement). As Jon Elster puts it, in a more modern idiom, 'emotions matter because if we did not have them nothing else would matter. Creatures without emotion would have no reason for living nor, for that matter, for committing suicide. Emotions are the stuff of life.' ${ }^{86}$ Hume also provides a basis for being sceptical about the whole enterprise of constructing 'heavens of laws'. The argument against heavens, whether earthly or other, may be said to lie somewhere close to the core of liberalism. Indeed, the very openendedness of liberal theory, its anti-perfectionist streak and concomitant tendency to deny its own absoluteness or finality, ought perhaps to be counted among its most distinctive features. And there is a relationship, Hume suggests, between scepticism (particularly of claims to authority) and liberty. As Russell Hardin (reworking Tocqueville) observes, liberals hold that it is not what is done by a liberal government but what is done under such a government by private agency that is the beauty and the good of liberalism'. ${ }^{87}$

\section{CONCLUSION}

The protagonist of Julian Barnes' novel A History of the World in 101/2 Chapters dreams of waking up in heaven. Things begin wonderfully. He's brought breakfast in bed. He finds his favourite clothes ironed and ready. He goes to a supermarket, stocked with everything. Even a transparent alcohol, Stinko-Parlytiko, promising to make you drunker than ever before. His football team, Leicester City, wins the F.A. Cup. ${ }^{88} \mathrm{He}$ starts playing golf. Soon he's hitting holes-in-one. He hangs out with famous people, even sleeps with some of them. Time passes. Naturally, after a while, he gets bored. 'It seems to me', he finally concludes, 'that Heaven's a very good idea, it's a perfect idea you could say, but not for us. Not given the way we are. ${ }^{89}$

Can the same be said of the inclusive theory - a very good idea perhaps, but not for us? I have argued that the dense thicket of laws articulated by that theory and designed to protect a thick network of social and political relationships leaves the individual immured within both community and state. In this context, Brudner's repetition of the word 'spontaneous' to describe individual life patterns ends up sounding like Orwellian doublespeak. I do not seek to challenge the republican insight that law is foundational to freedom. ${ }^{90}$ But such a thick legal

${ }^{86} \mathrm{Cf} \mathrm{J}$. Elster, Alchemies of the Mind: Rationality and the Emotions (Cambridge: Cambridge University Press, 1999) 403.

87 R. Hardin, Liberalism, Constitutionalism, and Democracy (Oxford: Oxford University Press, 1999) 6.

${ }^{88}$ For those unfamiliar with the intricacies of English football, this is a highly unlikely (although not strictly impossible) scenario.

${ }^{89} \mathrm{~J}$. Barnes, A History of the World in 101/2 Chapters (Picador, 1989).

90 P. Pettit, Republicanism: A Theory of Freedom and Government (Oxford: Oxford University Press, 1999). 
framework is problematic from the liberal standpoint, particularly since many of the laws and practices envisaged by the inclusive theory exhibit paternalistic features. The overdetermined life is a dull one. Unable to alter the conditions of existence, the individual would be bound once more to the wheel of fate.

The laws detailed by the inclusive constitution, moreover, are constitutional laws. This makes them largely immune from 'normal' politics and thus from the possibility of change. I will leave aside objections to the juristocracy that would result from such an enormous transfer of power to the courts. ${ }^{91}$ Nor do I wish to run an argument against constitutionalism per se. But constitutionalizing a detailed and highly prescriptive set of laws in the manner of the inclusive theory is to imagine a rigid and static polity that is a far cry from the dwelling-place of freedom of Brudner's imagining. Freedom may be said to dwell both within and outside constitutions. Removing ideological conflict - or subsuming such conflict into the pathways and processes of constitutional law - implies the 'cancellation' of real political contests between 'rival fundamental conceptions' or worldviews. Not only does this fly in the face of Machiavelli's insight (in the Discourses) that liberty is precisely the result of political conflict (or 'tumult'). ${ }^{92}$ But, at a broader level, the 'end of ideology 93 celebrated by the inclusive theory also amounts to the end of historical or secular time. ${ }^{4}$ Envisaging a state of political changelessness - a 'heaven of laws' - Constitutional Goods offers us not so much a constitutional theory but more a political theology. Those of us who are members of the Devil's party (whether we know it or not) will be quick to spot the tyranny at work in this particular heaven. ${ }^{95}$ The inclusive theory, as Raymond Geuss observes in a not dissimilar context, 'is a way of trying to immobilise society, to freeze it in an idealised version of its present form ... It is an attempt to ensure that the ghostly hand of the present is able to throttle the future. ${ }^{96}$ The overdetermined life might be boring. But the changeless one is stripped of meaning and purpose. The inclusive theory is not for us, then, not given the way we are.

${ }^{91}$ See R. Hirschl, Towards Juristocracy: The Origins and Consequences of the New Constitutionalism (Cambridge, MA: Harvard University Press, 2004).

92 N. Machiavelli, Discourses (Penguin, ed. B. Crick, 1983): 'To me those who condemn the tumults between the Nobles and the Plebs seem to be cavilling at the very thing that was the primary cause of Rome's retention of liberty ... And they do not realize that in every republic there are two different dispositions, that of the people and that of the great men, and that all legislation favouring liberty is brought about by their dissension.'

${ }^{33} \mathrm{CG}, 438$

${ }^{94}$ Compare Hume's 'The face of the earth is continually changing' from his essay on the original contract, or his belief that the 'world is still too young to fix many general truths in politics'.

${ }^{95}$ J. Milton, Paradise Lost, Book I: (Satan) -

'We may with more successful hope resolve

To wage by force or guile eternal Warr

Irreconcileable, to our grand Foe,

Who now triumphs, and in th' excess of joy

Sole reigning holds the Tyranny of Heav'n.'

${ }^{96}$ R. Geuss, History and Illusion in Politics (New York : Cambridge University Press, 2001) 154. 